Article

\title{
A Polyphonic Story of Urban Densification
}

\author{
Antti Wallin ${ }^{1, *}$, Helena Leino ${ }^{1}$, Ari Jokinen ${ }^{1}$, Markus Laine ${ }^{1}$, Johanna Tuomisaari ${ }^{1}$ and Pia Bäcklund ${ }^{2}$ \\ ${ }^{1}$ Faculty of Management, University of Tampere, 33014 Tampere, Finland; E-Mails: antti.wallin@uta.fi (A.W.), \\ helena.leino@uta.fi (H.L.), ari.jokinen@uta.fi (A.J.), markus.laine@uta.fi (M.L.), johanna.tuomisaari@uta.fi (J.T.) \\ 2 Department of Geosciences and Geography, University of Helsinki, 00014 Helsinki, Finland; E-Mail: pia.backlund@helsinki.fi \\ * Corresponding author
}

Submitted: 2 January 2018 | Accepted: 2 March 2018 | Published: 12 June 2018

\begin{abstract}
Urban strategies, representing stories of possible futures, often intervene in already established local communities and therefore call for a considerate urban intervention. This article utilises the ideas of Henri Lefebvre's socially produced space and of literature on stories involved in planning. Our empirical example tells a story of urban densification aspirations for an inner-city neighbourhood in Tampere, Finland. By combining the interviews of local people and planners with policy documents, we argue that planners' stories pay too little attention to the place and to local stories. Planners' abstract visions of the future and local stories building on lived experiences both draw meanings from the same place but have very different intentions. In our case, the consultation of the project started out wrong because the planners neglected a neighbourhood thick in symbolic meanings and the local stories' power in resistance. By understanding the place as polyphonic in its foundation, planners could learn about the symbolic elements and reasons for people's place attachment, and thus end up re-writing the place together. Urban interventions such as urban densification should connect to the place as part of its polyphonic historical continuum and acknowledge the residents' place attachments.
\end{abstract}

\section{Keywords}

Henri Lefebvre; place attachment; polyphony; spatial triad; stories; storytelling; urban densification; urban infill

\section{Issue}

This article is part of the issue "Urban Planning and the Spatial Ideas of Henri Lefebvre", edited by Michael E. Leary-Owhin (London South Bank University, UK).

(C) 2018 by the authors; licensee Cogitatio (Lisbon, Portugal). This article is licensed under a Creative Commons Attribution 4.0 International License (CC BY).

\section{Introduction}

Since the 1960s, the modernist way of urban planning has been criticised for homogenising cities and ignoring the citizens (e.g., Jacobs, 1961; Lefebvre, 1968/1996, 1974/1991). One of the first to address the contradiction between abstract urban planning and lived experiences was Henri Lefebvre, who advocated the citizens' right to the city (Lefebvre, 1968/1996, 1974/1991, pp. 396-397). Lefebvre notes how planners reduce the social space into an abstract space (Lefebvre, $1974 / 1991$, p. 370), hence resulting in the alienation of the citizens' lived experiences and supressing the everyday poiesis into dullness. Despite his critique of
Fordist-Keynesian capitalism and modernist urban planning as an elementary part of its spatial practice, he maintains his optimism and hope for humanism. The discontent against the modernist subordination of city life arouses countering forces that can confront this abstract conception of space (Lefebvre, 1974/1991, pp. 52, 391). Calls for making planning processes more aware of the citizens' opinions did inspire scholars and planners to develop participatory planning methods (Forester, 1989; Healey, 2007). But still, we seem to be far away from realising the citizens' genuine right to the city. Urban planning still neglects the place ${ }^{1}$ of the citizens and their stories (Hillier \& Van Wezemael, 2012; Sandercock, 2003).

\footnotetext{
${ }^{1}$ We adopt a conception of place as a signified space, thus distancing ourselves from the philosophical debate between space and place (e.g., Ingold, 2011, pp. 145-149; Lefebvre, 1974/1991; Massey, 2005).
} 
More recently, scholars of the "story turn" in planning (Sandercock, 2010, pp. 17-18) have highlighted rhetoric and visual presentations as crucial in communication and stories as catalysts in participatory planning procedures (Forester, 1989; Sandercock, 1998, 2010; Throgmorton, 1996). Cities are filled with collective and subjective representations (Eshuis \& Edwards, 2013); yet, plans tend to represent places as fixed. In practice, various actors socially produce places, making them relational depending on the perspective (Davoudi \& Strange, 2009, p. 5; Ingold, 2011, pp. 145-155). The dialectic of different stories shapes places through socio-spatial practices, leaving traces of "stories-so-far" on the urban landscape (Lefebvre, 1974/1991, p. 110; Massey, 2005, p. 9). If planners do not acknowledge local stories in any way, the legitimation of urban planning will become difficult. Our contribution in this article brings Lefebvre's spatial triad (1991, pp. 38-39; Leary-Owhin, 2016, pp. 14-15) and the literature on stories involved in planning together and reflects on these in a Finnish urban densification case. Plans are representations of space promoting a certain story for the future city, and their purpose is to control spatial practices producing the city. Planners' stories often conflict with the local stories, building on lived experiences in situ-its spaces of representation. Conflicting narratives affect how the place actually changes via concrete spatial practices of different actors, such as the planners, the constructors and the local people. We argue that one of the key questions is how to reconcile planners' stories, local stories and the place.

The importance of stories becomes evident in situations where the power relations of a planning practice change, as in our urban infill ${ }^{2}$ case of the inner-city neighbourhood of Tammela in the city of Tampere. The current case portrays a new situation in Finland: urban planners try to develop housing companies ${ }^{3}$ privately owned land, hence depending on local approval to proceed with their densification aspirations. Thus far, the city's planners have downplayed the importance of the place's history and locality, which are particularly thick in symbolic meanings. For planning to gain local support, it needs an orientation that connects the local stories with the abstract plans in a workable way. We will not take sides whether an infill development should or should not proceed, but rather emphasise the polyphonic nature of the place under planning. In the concluding part of the article, we return to the question of how planning practices should approach and bring forward the local stories representing a place.

\section{Stories Involved in Planning}

In this section, we describe our understanding of how the literature of stories involved in planning situates on
Lefebvre's spatial triad, and then formulate our analytical concepts. According to Lefebvre, planner's representations of space impose spatial practices that often conflict with the local spaces of representation, which users' lived experiences signify. The dialectic of planners' stories about the future and local stories built on lived experiences affect how the spatial practices of the citizens, planners and construction companies actually produce the place. Urban planning, indeed, is a field of conflicting stories that keeps on producing the city and attached meanings (Flyvbjerg, 1998). Thus, the city is a polyphonic story (Ameel, 2016; Ferilli, Sacco, \& Blessi, 2016), which offers "multiple trajectories" for planners to produce the city's future (Healey, 2007, p. 229; also Jensen, 2007, pp. 217-218).

The attention on stories in planning theory has been gaining importance since the 1990s, starting from James A. Throgmorton (1993, 1996, 2003), who argues that planning is persuasive storytelling. According to him, even though planners use disciplined and objective methods to abstract places into plans, more crucially, they use words to persuade others that their point of view is right for the practice. Throgmorton (2003, p. 146) notes that "powerful actors will strive to eliminate or marginalize competing stories, and that those powerful actors will include some planners to devise plans (stories about the future) that are designed to persuade only a very narrow range of potential audiences". Planners persuasively promote their representation of space by telling a story of the future, hoping it will affect spatial practices and result in an urban intervention.

The places where people live have a foundational story by which the identity of the place is constructed (Sandercock, 2003, pp. 17-18). Sandercock (2003, p. 18) argues that " $t$ ] he need to collectively change (and represent in the built environment itself) these old foundational stories are one of the contemporary challenges facing planners". The local people acknowledge the symbolic elements of the place. These spaces of representation become apparent when they tell stories of that particular place. Thus, planners' abstract strategies threaten to change these foundational stories, generating opposition in the neighbourhood. Still, Sandercock $(2003,2010)$ argues that "planning as performed story" can help planners perform better by expanding practical tools, by sharpening critical judgement and by widening the circle of democratic discourse. Likewise, van Hulst (2012) promotes a more inclusive method to incorporate local stories into institutional planning. Goldstein, Wessells, Lejano and Butler (2015, p. 1300) go further, arguing that "[c]ommunities need to tell their own stories in order to identify system properties that are meaningful and compelling and enhance their personal and collective agency". Narration can thus increase the community's re-

\footnotetext{
${ }^{2}$ Urban infill refers to a practice of building flats into vacant or underused spaces on a housing lot to densify the urban structure (see Tampere, 2015).

${ }^{3}$ A housing company is a limited liability company if its purpose is the ownership and possession of one or more buildings. The dwellers own shares of the company, giving them the right to live in a certain flat. The shareowners elect a managing board amongst themselves. They often have little or no background in housing policy and urban development, which often poses challenges for decision-making. In Finland, $57.3 \%$ of the dwellings are owner occupied, $31.2 \%$ are rental, and the remaining $11.5 \%$ have miscellaneous types of tenure (Statistics Finland, 2017a).
} 
silience by helping it to adapt to changing circumstances (Goldstein et al., 2015, p. 1287). Even though scholars acknowledge the importance of listening to local stories, they often seem subordinate to planners' stories.

Soja (2003) criticises Throgmorton's persuasive storytelling of neglecting spatiality. Throgmorton (2003, p. 134) acknowledges the need for spatialising the storytelling imagination and underlines planning taking place in "a global-scale web of relationships". Global competitive strategies become visible in local places, which is why Jensen (2007, pp. 212-217) calls for planners to adopt spatially sensitive narratives to acknowledge the lived space meaningful for local people. With a similar orientation, Childs (2008, p. 184) writes: "[l]istening to stories of place can inform designers about the narrative fabric that is as much a critical part of the context of a site as the soil type". Planners' abstract plans and lived local stories both stem from the same place. Thus, through spatial practices, they also keep on re-writing the stories-so-far of the urban landscape. The multiplicity of citizens' voices therefore contests the place and its foundational story. Hillier and Van Wezemael (2012) argue that planning procedures should allow participants to experience place from many perspectives. Kornberger (2012, pp. 101-102) notes that planners' "strategy will always, at least partially, fail to determine the future because agents may use, abuse and sometimes subvert strategies". The city's future remains open because contesting spatial practices socially produce it.

Returning to Lefebvre's ideas, we find that the stories involved in planning have much in common with the social production of space. It is hard for planners to reduce the multiplicity of local voices into a compelling representation of space, especially when the purpose is to tell a new story for the future of the place. The local stories built on the lived experiences and highlighting the spaces of representation easily conflict planners' representations. Rather than just trying to integrate local stories into plans, we suggest underlining the actual reasons for people's place attachment and the character of the place. Therefore, we want to address the place as a polyphonic story, which intertwines the planner's stories, the local stories and the place itself. Those three elements are:

a) Planners' stories: referring to conceived space and representations of space, as they are mental abstractions of social space, often lacking the local stories for planning. By persuasive storytelling, planners then promote this conception of a possible future to local people or construction companies and politicians;

b) Local stories: referring to the lived experiences and spaces of representation. Local people narrate symbolic meanings to a place through memories and past events. The everyday life differs from abstract plans; as a result, local stories will take an antagonistic position if they do not share plan- ners' conception of the future. Therefore, counternarratives are likely to appear when planners appoint the place under planning;

c) The place: referring to perceived space and spatial practices. From the analytical standpoint, deciphering the place reveals society's spatial practices (Lefebvre, 1974/1991, p. 38). The spatial underpinning is the source for both stories, but through socio-spatial practices, the place and its symbolic meanings are constantly re-written. Despite its constant changing, the place always accommodates the stories-so-far and offers material referents to place attachment, as well as imaginary elements for planners' spatial abstraction.

\section{Methodology}

Planning scholars often use narrative analysis (Landmann, 2012, pp. 32-33). In stories, the narrator recounts the event, the meanings and feelings associated with it and its implications. Narratives deal with the complexities of real life and are often hard to summarise under neat categories (Flyvbjerg, 2001, p. 84). However, "hardto-summarise" narratives provide insight into the complexities and contradictions a given urban intervention involves (Landmann, 2012, p. 29). In our empirical example, we wanted to discover how the planners and the local dwellers experience and represent the urban infill process. Tammela's densification as a "critical case can be defined as having strategic importance in relation to the general problem" (Flyvbjerg, 2001, p. 78). Thus, learning from the difficulties in Tammela may also add to the understanding of other planning cases, especially in urban densification areas.

We examined the policy documents of Tammela's densification project published on the city of Tampere website (Tampere, 2018), and used them as background information to understand the timeline of the process and to contextualise the interviews. By carefully reading the core documents (e.g., Vision of Tammela, 2012) and the documents related to the city strategy-making (e.g., Tampere, 2015, 2016), we interpreted how they represented Tammela and the city development. We then analysed the planners' stories more closely by interviewing seven people working on the area's urban infill. Five of them were municipal officials from the city of Tampere, and two were self-employed consulting architects. These interviews concentrated on how planners experienced the process of Tammela's urban densification project and the city strategy-making; the interviews lasted from one to three hours and were conducted in 2016. In the spring of 2016, we constructed an interview frame from the policy documents and prepared students of Regional Studies and Environmental Policy to gather the local dwellers' stories. To have a general idea of the neighbourhood, the students interviewed 43 people in Tammela: 10 people working in the area and 33 people living in the neighbourhood. The discussion focused on 
how they saw the past and future of Tammela and what they thought of the urban infill plans. These interviews lasted from 30 minutes to one hour.

We analysed the transcribed interviews in Nvivo (e.g., Bailey, Devine-Wright, \& Batel, 2016, p. 203). Our analysis sought to understand what kind of story the interviewee was trying to tell about the place through the inclusion of certain aspects and the choice of words and phrases; this helped us understand the story told and thus the storyteller (Maynard-Moody \& Musheno, 2006, p. 320). By categorising popular themes concerning Tammela's history, the urban infill strategy and the locality, we examined how the planners' stories and local stories collided. While analysing the interviews, it became obvious that the planners and the locals built very different understandings of the place, which could be the most important reason behind the tensions between them. The planners primarily view Tammela as an instrumental place for the city's development, and from that position, tell stories of the problematic planning procedure. The local dwellers' interviews have diverse content and a less straightforward stance toward the densification. Our epistemic position is to view the planning process and the place itself as polyphonic and relational; we are not looking for a universal foundational story, but rather, want to learn from the planning process through narration.

\section{A Place in Transition}

The driving force of our story originates in a typical transition from a blue-collar city to a knowledge and culture city, compelling the city officials and politicians to draw a new urban strategy (Gressgård, 2015, p. 112; Sandercock, 2003). Tampere is located in southern Finland on an isthmus of two lakes with a rapid in the middle, which early on provided energy for factories. It has been a major industrial city, but during the last few decades, its economy has centred on high technology and services. Still, the population of Tampere grows steadily. In the past 30 years, its population grew by 60,000 to the current 228,000 inhabitants, and the municipal officials project it to receive 40,000 new inhabitants by the year 2040 (Tampere, 2014, 2016). Until recent years, Tampere sought growth from suburbanisation, but now the trend is to intensify urban structure to prevent growth from slipping into neighbouring municipalities (Vision of Tammela, 2012). Politicians and urban planners drew a new strategy to boost the population and economic growth by promoting urbanism: improvement of public and private transportation, largescale construction projects and infill development of the existing urban structure (Tampere, 2015, 2016).

The inner-city neighbourhood of Tammela (population of 5,646; see Tampere, 2014) is an essential part of Tampere's urban densification strategy. In the first half of the 1900s, citizens considered Tammela the capital of cobblers because of its concentration of Finnish shoemakers. Being a central industrial location, it was a large working-class neighbourhood with the city's main market place. Tammela's urban landscape consisted mostly of workers' wooden houses and red brick factory buildings (Vision of Tammela, 2012, pp. 16-20). After the Second World War, Finnish urbanisation drew people in from rural to urban areas, causing an acute housing shortage. Concurrently, modernist orientation to urban planning triggered a major renovation of cities as a part of social development (Hankonen, 1994), and the 1966 plan of Antero Sirviö transformed the neighbourhood of Tammela. The city developers demolished most of the wooden buildings, and the tenants needed to relocate to housing projects further from the city's centre (Koskinen \& Savisaari, 1971). Sirviö planned eightstorey, pre-cast concrete blocks of flats to intensify the urban structure and to improve the citizens' poor housing conditions. He preserved Tammela's historical grid plan, but in many cases, the developers built the new housing estates in the centre of the building lots, leaving large areas for parking lots and unused green areas. After the massive urban renovation in the 1970s, the following decades saw only moderate changes in Tammela's urban landscape. One by one, factories were closed and transformed into flats. Residents changed, and as a reaction to the social change of the place, the citizens recognised Tammela's renewed image and re-constructed identity. Tammela's neighbourhood association honoured the place thick with symbolic meanings, organised events and published books of its history (Wacklin, 1997, 2008). The local residents now recognise the urban landscape as representing stories about its working-class history with its few remaining wooden buildings and historic factories, but also about its massive post-war social change with the concrete blocks of flats. Tampere's growth re-emphasises Tammela's significance in its urban structure, raises housing prices, ${ }^{4}$ and increases the political interest to pursue densification (Table 1).

In 2008, planning officials began to investigate Tammela's densification. In September 2009, the municipal executive committee designated it as the first neighbourhood for urban infill planning (Vision of Tammela, 2012, p. 7). Planning officials realised that with the infill development of the relatively loosely built blocks of the 1970s, Tammela would have the potential space for 4,000 new inhabitants. In April 2011, municipal officials held a professional opening seminar for Tammela's densification project in the City Council Hall (Vision of Tammela, 2012, p. 14). Planning officials' unfinished and unpublished vision of Tammela's infill development was leaked on the Internet, showing a date of 11 June 2012 (Vision of Tammela, 2012). On 18 June 2012, the municipal executive committee accepted the Vision of Tammela (2012) as the basis for infill development, and planners then introduced it to the local area. Later on, they integrated

\footnotetext{
${ }^{4}$ The average price of flats increased by 33\%, to $3063 € / \mathrm{m}^{2}$, between 2007 and 2016 (postal code 33500; Statistics Finland, 2017b).
} 
Table 1. Timeline of Tammela's urban densification planning.

\begin{tabular}{ll}
\hline 2000 & First steps in inner-city infill development. \\
\hline September 2009 & Municipal executive committee designates Tammela as a pilot area for infill development. \\
\hline April 2011 & Municipal officials hold an opening seminar for the professionals. \\
\hline September 2011 & $\begin{array}{l}\text { The mayor appoints an evaluation group consisting of } 10 \text { professionals and one representative from } \\
\text { Tammela's neighbourhood association. }\end{array}$ \\
\hline June 2012 & $\begin{array}{l}\text { The Vision of Tammela is leaked on the Internet and the municipal executive committee ratifies it as } \\
\text { the basis for the infill development. }\end{array}$ \\
\hline $2012-2014$ & $\begin{array}{l}\text { Planning officials organise public hearings on individual planning cases, not about the vision as such. } \\
2014-2017\end{array}$ \\
$\begin{array}{l}\text { City officials hire consulting architects to approach housing companies and to draw block plans of } \\
\text { suitable infill development. }\end{array}$ \\
\hline
\end{tabular}

the project into the larger city strategy-making (Tampere, 2015, 2016). Tammela's densification vision was an ambitious and extensive regeneration plan, but it remained a purely technical performance without public consultation before it was made public in 2012. During 2012-2014, the city arranged public discussions regarding a street plan and a football stadium in Tammela. The public, however, wanted to discuss the Vision of Tammela document in these hearings because they had had no previous opportunities to talk about it. Tammela's densification faced severe problems in its implementation. Resident-owned housing companies, which possess most of the land, were unwilling to develop their lots. The future of the densification process depends on these land-owning housing companies, but the first plans did not incorporate any aspirations of the dwellers. The Vision of Tammela $(2012$, p. 5) presents the need for densification as following:

Stopping the diffusion of urban structure is one of the most important challenges for urban planning. The constant expansion of urban structure causes additional costs for maintaining the infrastructure and the service network, and an ecological burden by increasing traffic flows....Growth pressure has to be directed in a controlled manner to attract inhabitants and businesses, new housing and jobs, without destroying the identity, appeal and natural boundaries.

The densification plan represents a holistic answer to contemporary urban questions, but at the same time, it homogenises the place to merely another problem in urban development (Lefebvre, 1974/1991, pp. 287-288, 341-342). The planners' abstract vision of the dense urban form follows the example of Vancouver, Canada, and its strategy for promoting urbanism (Vision of Tammela, 2012, p. 10; see also Leary-Owhin, 2016). Their urban infill vision leaned on objective reasoning and technical visualisations (Figure 1). However, Tampere's planning officials underestimated the power of local stories and housing companies. From 2012 onwards, the city officials continued the business-as-usual kind of participatory plan- ning practice with conventional public hearings (Leino \& Laine, 2012; Leino, Santaoja, \& Laine, 2017) and assumed housing companies would eventually sell building rights to the construction companies. However, the planners' story of the future Tammela remained abstract, without recognising the local stories and respecting the neighbourhood's symbolic elements (Ameel, 2016; Sandercock, 2010).

\section{From Abstract Strategy to Locality}

As soon as the problems became clearer, the planners decreased the expected population growth from 4,000 to 2,500 because the urban infill "would probably materialise over a very long period" (Tampere, 2016, p. 46). During 2012-2015, they continued persuading the public with their holistic story, in which they had great belief. One architect states the following:

You must have an idea. A dream, a vision and a concept, then they realise its value. Then we start executing it and enhancing it even further, the ones we can. And in the end, through the process with the participants, it becomes better. Or this is how we thought it would be. (Planning architect)

As Lefebvre notes (1974/1991, pp. 75-76), "[w]e build on the basis of papers and plans. We buy on the basis of images". Thus, being able to tell and represent a compelling story is central to contemporary planning practice (Sandercock, 2003; Throgmorton, 2003). The planners of Tammela understood the strategic importance of persuading the local people. They believed their story was impressive and thorough enough, but they did not induce it from the locality. Kornberger (2012, p. 91) writes that "strategy offers a platform for envisaging a big picture that represents a shared future uniting people beyond the differences and conflicts of today". Tammela's case lacked this aspect of strategy-making. The city officials were unable to understand why the locals did not accept their story. Gressgård (2015, p. 117; see also Lefebvre, 1974/1991, p. 371) notes that "[u]rban strat- 


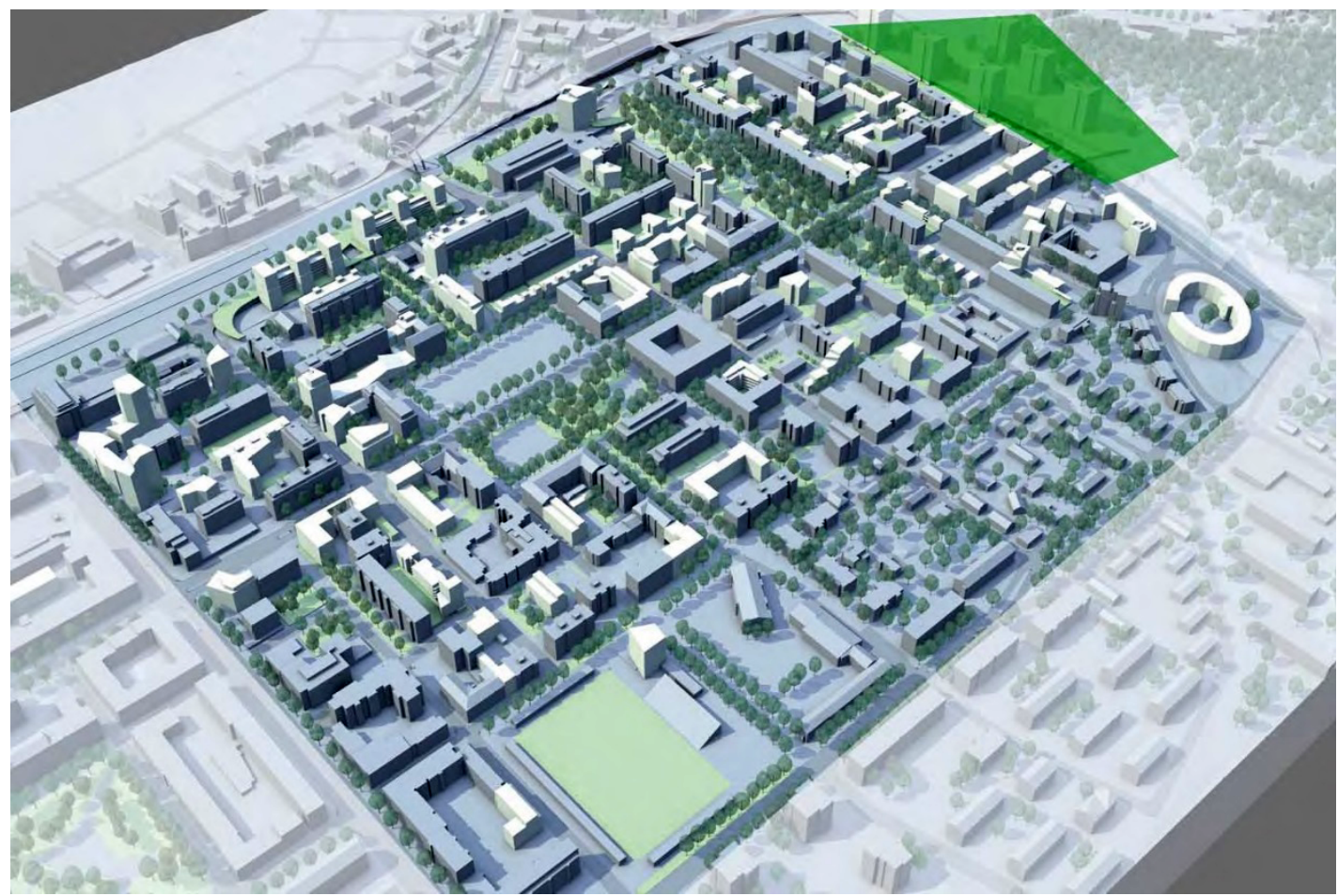

Figure 1. Vision of Tammela's densification potential (Vision of Tammela, 2012, p. 40). The lighter buildings represent possible new buildings. Later on, planners promoted an even more ambitious densification vision, for example, to build 12-storey apartment buildings around the football stadium (centre-bottom).

egy works to establish a fully-fledged structural totality that forecloses alternative meanings of cultural elements and relations". The vision of Tammela's (2012) future was a spatial abstraction drawn at the planners' desks - the place was special only as a useful piece of land for the city's development. In this document, planners used historical images to raise the symbolic value of the neighbourhood but did not acknowledge the postwar development or effects on people's everyday living. Planning officials aimed their argument for the political audience by presenting the infill development as being two to 10 times more economically efficient than building more developments in the suburbs (Vision of Tammela, 2012, p. 43). The economic growth agenda drove the densification policy and focused primarily on representing the objective examination of the targeted building volume increase. Consequently, the planners ignored the stories of the neighbourhood's symbolic history and place attachments.

Because of the public's reluctant reception, in 2014, planning officials began to direct resources to work on single blocks, besides the whole neighbourhood project. City officials hired consultants to continue the persuasive storytelling and to listen to local voices (see Hillier \& Van Wezemael, 2012, pp. 325-326). Trying to find ways to unlock the situation, the consultants organised workshops directly for the housing companies:

Usually in these sorts of projects, it [city planning policy] has counted on the work of professionals- thinking that the professionals know what's happening in the neighbourhood, but actually this is not the case at all. (Consulting architect)

Finnish urban planners experience interaction with the local dwellers as difficult (Leino \& Laine, 2012). Even though participatory planning methods have developed in Finland, the planners usually continue to follow the same routine; they abstract the place into a plan and simultaneously lose something essential about the lived space: its symbolic meanings, history and culture. Tampere's planning officials promoted their vision in public hearings and participated in the debate, yet the gap between abstract planning and local life remained wide, as one resident noted:

[T]hese public hearings have quite often led to heckling and jeering. The ones I've been to have not been really good spirited. And then there's a bit of that, that the city officials don't have that common know-how, for example when someone asks a difficult or even a stupid question, they don't know how to answer. They just don't understand what the people are asking. (Local resident)

Following Lefebvre, Healey (2007, pp. 242-243) notes that planners are an "inside" community shaped within the epistemic community of practices. The residents of a particular place develop an experientially acquired "Iocal knowledge" of specific conditions, knowledge that dif- 
fers from the planners' knowledge (Healey, 2007, p. 243; Leino \& Peltomaa, 2012). There are two very different modes of storytelling in action, but the object is the same: they both draw meanings from the place itself. Yet the participation often remains just rhetoric, allowing for no strategic agency for the plurality of visions (Hillier \& Van Wezemael, 2012, pp. 321-326). In some cases, the residents of Tammela show signs of alienation from urban development; the planners' story is out of their control:

The thing I oppose the most in these changes is that I believe the construction companies collect big profits because they are listed companies and their most important goal is [increasing] the shareholder value. They are not interested in small people's opinions. In addition, the new flats are expensive. (Local resident)

Some participants described Tammela's urban regeneration as "being made for people with deep pockets" (Local male pensioner). The common understanding among the local dwellers is that the banks, the construction companies and the local politicians make decisions about the city without any regard to the citizens' opinions (see Lefebvre, 1968/1996, pp. 167-168). These experiences are rooted in the long tradition of Finnish modernist planning (Hankonen, 1994; Koskinen \& Savisaari, 1971; Puustinen, Mäntysalo, Hytönen, \& Jarenko, 2017). The distrustful narratives have a visual reminder in Tammela's urban landscape: the 1970s' top-down renovation of the neighbourhood (Koskinen \& Savisaari, 1971). Likewise, the new densification plan and the residents' everyday lives in the neighbourhood remain apart. Even though planners began to organise public hearings after 2012, people remained wary because the densification could change the character of the place-by gentrification and losing its symbolic meanings (see Figure 2).

\section{Character of the Place and Place Attachment}

The strategic plans felt alien to the local people but so did the specific locality to the planning officials. The planners' persuasive storytelling was about changing the city-not the community. The previously published neighbourhood histories and Tammela's symbolic meanings were absent from the plans. Likewise, the city officials included the regional museum's expertise in the planning process only in a minor commenting role. Planning officials recognised Tammela's strong identity and historical significance for the locals but seemed to lack the tools for incorporating them into the plans. The Vision of Tammela $(2012$, p. 25) points out that the modernist renovation of the 1970s is a mistake needing a repair, and by ignoring the locals, planners belittle the past 40 years of lived experiences. The following city strategy (Tampere, 2015, 2016), on the other hand, brands the city as ahistorical: working-class history is irrelevant when telling a story about the city's future. The planners treated the place as an abstract representation of a desirable future, as one official involved in evaluating the city strategy-making described:

I was left feeling that it (Vision of Tammela, 2012) was pulled out of an architect's hat. That the urban space

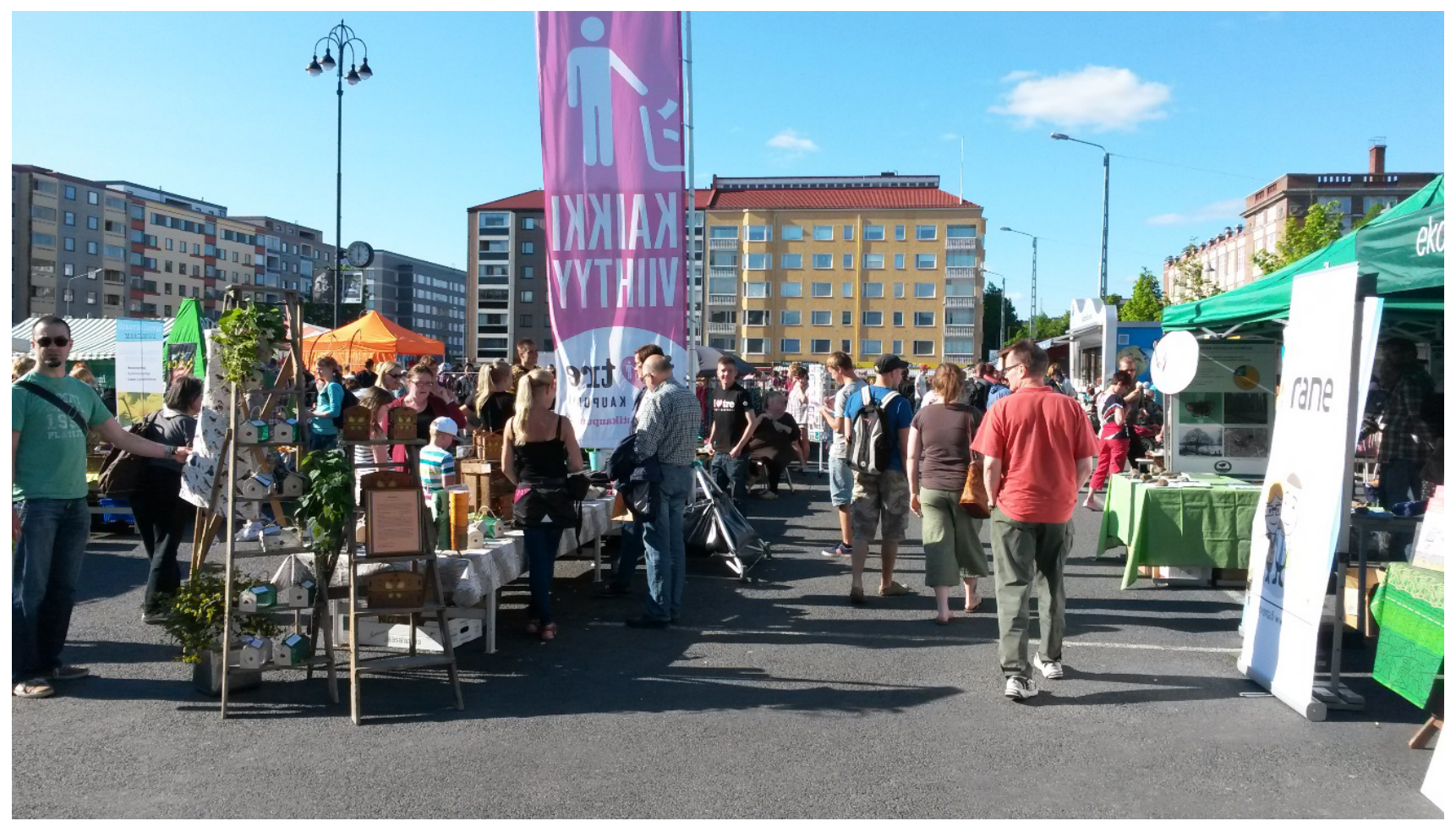

Figure 2. A view of Tammela's market place on 1 June 2014. Photo by Minna Santaoja. 
had somehow failed and something had to be done about it....The attitude was like "I'Il plan this into order", just as was done in the sixties and seventies, and now we criticise that back then problems were solved by planning, rationalising, measuring, and calculating. Should we now have another element involved? (Municipal official)

Lefebvre (1974/1991, p. 99) argues that planners view themselves as "doctors of space", offering cures for the sickness of society. This leads the planning procedure to fix the place as given and dissipating the experienced place with different realities and desires (Hillier \& Van Wezemael, 2012, pp. 321-326). During its history, dwellers built distinct narratives of Tammela's industrial past, its major urban renovation in the 1970 s and, more recently, its multifaceted urban life. The change in Tammela's significance in urban structure, its vivid urban culture and layered landscape transformed the place into a more colourful neighbourhood than a regular workingclass one. A bartender described it: "We're like a 1970s' hippie community. Nobody is treated like a stranger and looked down on. Everybody fits in here" (Local resident). Tammela's urban landscape contains symbolic elements of past eras to which people attach different meanings. The interpretations of the place change via people's everyday practices, yet the past always leaves traces on the landscape (Childs, 2008; Lefebvre, 1974/1991; Massey, 2005):

My child and I have friends living in the former Aaltonen shoe factory, and we used to live in the former Brander shoe factory, and then there's the Attila factory. Yeah, I know the history. This has been the cobblers' neighbourhood but that doesn't have any connection with my life now. These flats where we live have also been factory workers' dwellings. It is an essential part of the history but nowadays it doesn't show in anyway in the milieu, except that those old factory buildings exist. (Local resident)

There is always a multiplicity of local narratives (Ameel, 2016, p. 36). The identity and character of the place differ depending on the perspective, and these different origins for place attachment are difficult to recognise in the planning process (Hillier \& Van Wezemael, 2012). For the younger residents, historical symbols do not have significant personal meaning, but they see Tammela as a place with an energetic cultural life. In contrast, the elderly residents identify with its strong working-class history. Still, they all attach meaning to the place through their lived experiences.

According to Lefebvre (1974/1991, p. 94), "[s]pace is a social morphology". The place represents more than just the memories attached to them-it also signifies the stories of its users. Its spaces of representation speak (Lefebvre, 1974/1991, p. 42). The most iconic symbolic place is Tammela's market place (Figure 2), a popular gathering place for older people. Many interviewees describe the place as having an illicit history of black market alcohol sales, as the narratives of the market place regulars show: "This here is the wet side and that there is the posh side" (Male pensioner). The urban landscape is the reference into which people narrate place attachment. From this perspective, local people might view a complete remodelling of the market place as a personal threat, as the following interview shows:

Male pensioner: This (market place) is a very good place in every way. This hasn't been ruined yet. They've been planning a lot, building castles in the sky and underground parking garages, and sure, they want to ruin everything.

Interviewer: Are you opposing those plans?

Male pensioner: Absolutely. The surroundings have already changed a lot, so these few that remain shouldn't be taken. It used to be all wooden houses here, and that building used to be a medicine factory. My grandpa used to live here.....In the 1950s, when there was hardly any asphalt anywhere else, but they were laying it down here, we used to come here and swerve our bikes. God damn, it was fine doing wheelies here because the cobblestone or gravel roads everywhere else would vibrate the fat tyres....It has a big meaning in my life. (Local resident)

By attaching meaning to the neighbourhood and its symbolic places, the urban landscape constructs the setting of personal events in people's life stories. And so, as in the interview, a radical urban intervention might attack them and their histories. For the younger generations, it seems easier to envision the planners' persuasive storytelling and welcome the urban intervention. For the older residents, the abstract storytelling remains distant because they are used to living in an area that has changed relatively slowly. The question is not whether people are for or against the infill development, but rather, whether they can envision their life in relation to it. Place attachment is about settling in a networked geography of places (Savage, Longhurst, \& Bagnall, 2005, pp. 207-208). As Savage et al. (2005, p. 207) argue, “[p]laces are defined not as historical residues of the local, or simply as sites where one happens to live, but as sites chosen by particular social groups wishing to announce their identities". The people who were working in Tammela but living elsewhere also loved the place. There are always multiple local narratives, of which some remain hidden (van Hulst, 2012, p. 313). Therefore, it would be naïve to expect planners to find one foundational story on which to draw a legitimate urban infill plan. Rather, as Ameel (2016, p. 36) suggests, for the "idea of the city as repository of multiple narratives, and the desire to incorporate these into a democratic and inclusive form of planning, a first important step would be 
a heightened awareness about the narrative complexity of an area".

As Massey (2005, p. 125) notes, “[y]ou can't hold places still". Places and people change in myriad ways, but it is still important to acknowledge the attachment to and the character of the place in the planning process. After the planning officials had hired consulting architects to promote infill development on the block scale directly to housing companies, the housing companies on three different blocks decided to proceed with the planning process (Tampere, 2017). By organising several workshops and respecting residents' desires, the consulting architects were able to build a discussion forum on: the suitable building volume increase, design and compensations for selling shares for the construction companies. The city of Tampere also endorses the negotiations by promising significant discounts on land use fees for infill development projects (Tampere, 2017, p. 12). Hillier and Van Wezemael (2012, pp. 325-326) note that planners recognise the residents' place attachment more profoundly when they conduct the participation process on a smaller scale. However, the consensus of the neighbourhood's future character remains elusive. Because the Finnish planning procedure increasingly emphasises the importance and convenience of strategic planning over statutory planning (Mäntysalo, Kangasoja, \& Kanninen, 2015), the storytelling for the future should be founded on the polyphonic history and character of the place to gain better legitimation among the citizens.

\section{Conclusions}

Lefebvre's (1974/1991, pp. 105-106) warnings of reducing lived experiences into an abstract space remain philosophical. Therefore, we need practical tools to improve planning practices, and the storytelling imagination can offer an approachable contribution. The problem in several planning processes is that various kinds of stories about a place do not meet, let alone converse with each other. Planners' abstract story of the future subordinates local stories and the place with its symbolic meanings; thus, it ignores alternative futures (Gressgård, 2015, p. 117; Hillier \& Van Wezemael, 2012; Lefebvre, 1974/1991, pp. 370-371). The identity of the place changes and planners need to recognise it (Sandercock, 2010 , p. 25). Currently, many scholars argue for applying the multiplicity of local stories in planning processes to ensure our cities remain humane, inclusive and diverse (e.g., Ameel, 2016; Ferilli et al., 2016; Sandercock, 2010). The local stories can tell planners what is meaningful about the place (Hillier \& Van Wezemael, 2012, pp. 327-328; Jensen, 2007; Soja, 2003). Therefore, Childs (2008, p. 184) suggests that "urban designers should create anthologies of neighborhoods' stories to help inform projects, and otherwise serve as curator and advocate for the vitality of the narrative landscape". Following Lefebvre (1991, p. 365), to transcend the planners' representations of space and representational spaces of the locality we need to recognise the place as expressing socio-political contradictions. The residents should tell the story for the way forward in conjunction with the planners, thus including the place and the stories-sofar in the urban landscape (Massey, 2005; Sandercock, 2010, p. 25).

In our case, the story of Tammela is now at a turning point. The current urbanisation process generates political pressure for infill development. However, the residents rejected the planners' holistic densification plan for the neighbourhood. Why this happened, we argue, was because the planners started the process without consulting the local people, even though the land ownership was in local hands. The planners disregarded the local stories, the reasons for people's place attachment and the local power in resistance. Afterwards, the municipal officials, with the help of consulting architects, focused their persuasive storytelling on a concrete block level and tried to interact more closely with the residents. The smaller scale participation received some success, but more public envisioning is needed if the neighbourhood's future story is to gain wider acceptance.

The production of a neighbourhood is a complex ensemble of stories stemming from the planners' desks, dwellers' lives and symbolic elements of the place. We believe that making this polyphonic story more transparent will help the planning process to gain the legitimacy needed to proceed or force planners to re-evaluate their premises. The planners' practice of abstracting the place into plans alienates the citizens' voices from the development, but it also estranges planners from people's lived space. It is necessary to have planners participate in the social interaction to understand the reasons for people's place attachment. Despite the risks of planning officials potentially losing some control of their institutional expertise, public participation calls for experimental approaches (Hillier \& Van Wezemael, 2012, p. 327). Nevertheless, some people always decide to remain aside from the participation process, and planners want to silence some inconvenient stories (Lefebvre, 1974/1991, p. 365; van Hulst, 2012, p. 313). Consequently, planners need to acknowledge the minorities and marginalised communities and overcome the participation for the sake of it (Ferilli et al., 2016, p. 99). Local people interact with each other and produce collective representations (Eshuis \& Edwards, 2013), which can also arouse resistance and counter-action from bottomup (Lefebvre, 1974/1991, pp. 381-383). According to Lefebvre (1974/1991, pp. 419-420), discussing the views of locals and planners is a measure of a real democracy. Forester $(2009$, p. 187) notes that it is more difficult to hurt each other when we know one another's stories. We recognise the risk of immersing oneself in memories and refusing all development (Forester, 2009, p. 106). Instead, we propose an idea of the place as changing and relational while acknowledging the history of the place (stories-so-far) for its future users and residents (Massey, 2005). We promote an orientation in which planners' sto- 
ries, local stories and the place together composes a polyphonic story.

In Tammela's case, the planners' abstract representation of space projected into an established neighbourhood was destined to fail. Undoubtedly, the planning for Tammela raised issues that concerned the locals, but also the specific locality raised issues that the planners did not understand. Moreover, there will be other issues that cannot yet even be imagined. Smaller scale participation and genuine recognition of lived experiences and symbolic elements, we believe, would result in better planning. The more planners can include the multiplicity of local stories into their representations, the more they will appreciate the differences in experiencing the place. Not all aspects of the future can be favourable for everyone, but envisioning the way forward together with the planners and locals is still a more democratic way to change a place.

\section{Acknowledgments}

This research was conducted within the project 'Strategic spatial planning with momentum gaining scenario storytelling: Legitimacy contested? (2016-2019)' generously funded by the Academy of Finland [project 289691].

\section{Conflict of Interest}

The authors have no conflict of interest to declare.

\section{References}

Ameel, L. (2016). Narrative mapping and polyphony in urban planning. Yhdyskuntasuunnittelu, 54(2), 20-40.

Bailey, E., Devine-Wright, P., \& Batel, S. (2016). Using a narrative approach to understand place attachments and responses to power line proposals: The importance of life-place trajectories. Journal of Environmental Psychology, 48, 200-211.

Childs, M. C. (2008). Storytelling and urban design. Journal of Urbanism: International Research on Placemaking and Urban Sustainability, 1(2), 173-186.

Davoudi, S., \& Strange, I. (Eds.). (2009). Conceptions of space and place in strategic spatial planning. London: Routledge.

Eshuis, J., \& Edwards, A. (2013). Branding the city: The democratic legitimacy of a new mode of governance. Urban Studies, 50(5), 1066-1082.

Ferilli, G., Sacco, P. L., \& Blessi, G. T. (2016). Beyond the rhetoric of participation: New challenges and prospects for inclusive urban regeneration. City, Culture and Society, 7(2), 95-100.

Flyvbjerg, B. (1998). Rationality and power: Democracy in practice. Chicago, IL: University of Chicago Press.

Flyvbjerg, B. (2001). Making social science matter: Why social inquiry fails and how it can succeed again. Cambridge: Cambridge University Press.

Forester, J. (1989). Planning in the face of power. Berke- ley, CA: University of California Press.

Forester, J. (2009). Dealing with differences: Dramas of mediating public disputes. Oxford: Oxford University Press.

Goldstein, B. E., Wessells, A. T., Lejano, R., \& Butler, W. (2015). Narrating resilience: Transforming urban systems through collaborative storytelling. Urban Studies, 52(7), 1285-1303.

Gressgård, R. (2015). The power of (re) attachment in urban strategy: Interrogating the framing of social sustainability in Malmö. Environment and Planning $A$, 47(1), 108-120.

Hankonen, J. (1994). Lähiöt ja tehokkuuden yhteiskunta [Housing estates and the society of efficiency]. Tampere: Otatieto \& Gaudeamus.

Healey, P. (2007). Urban complexity and spatial strategies: Towards a relational planning for our times. London: Routledge.

Hillier, J., \& Van Wezemael, J. (2012). On the emergence of agency in participatory strategic planning. In G. de Roo, J. Hillier, \& J. Van Wezemael (Eds.), Complexity and planning. Systems, assemblages and simulations (pp. 311-332). Surrey: Ashgate.

Ingold, T. (2011). Being alive. Essays on movement, knowledge and description. London: Routledge.

Jacobs, J. (1961). The death and life of great American cities. New York, NY: Random House.

Jensen, O. B. (2007). Culture stories: Understanding cultural urban branding. Planning Theory, 6(3), 211-236.

Kornberger, M. (2012). Governing the city. From planning to urban strategy. Theory, Culture \& Society, 29(2), 84-106.

Koskinen, T., \& Savisaari, A. (1971). Onni yksillä-pesä kaikilla. Tutkimus Amurin ja Tammelan saneerauksesta Tampereen kaupungissa [Happiness for somehome for all. Study of urban regeneration in Amuri and Tammela in the city of Tampere]. Tampere: Tampereen yliopiston tutkimuslaitos.

Landmann, T. (2012). Phronesis and narrative analysis. In B. Flyvbjerg, T. Landmann, \& S. Schram (Eds.), Real social science: Applied phronesis (pp. 27-47). New York, NY: Cambridge University Press.

Leary-Owhin, M. E. (2016). Exploring the production of urban space: Differential space in three post-industrial cities. Bristol: Policy Press.

Lefebvre, H. (1991). The production of space (D. Nicholson-Smith, Trans.). Oxford: Blackwell. (Original work published 1974)

Lefebvre, H. (1996). Right to the city. In E. Kofman \& L. Elizabeth (Eds. \& Trans.), Writings on cities (pp. 61-181). Oxford: Blackwell. (Original work published 1968)

Leino, H., \& Laine, M. (2012). Do matters of concern matter? Bringing issues back to participation. Planning Theory, 11(1), 89-103.

Leino, H., \& Peltomaa, J. (2012). Situated knowledgesituated legitimacy: Consequences of citizen partici- 
pation in local environmental governance. Policy and Society, 31(2), 159-168.

Leino, H., Santaoja, M., \& Laine, M. (2017). Researchers as knowledge brokers: Translating knowledge or coproducing legitimacy? An urban infill case from Finland. International Planning Studies. https://doi.org/ 10.1080/13563475.2017.1345301

Mäntysalo, R., Kangasoja, J. K., \& Kanninen, V. (2015). The paradox of strategic planning: A theoretical outline with a view on Finland. Planning Theory \& Practice, 16(2), 169-183.

Massey, D. (2005). For space. London: SAGE.

Maynard-Moody, S., \& Musheno, M. (2006). Stories for research. In D. Yanow \& P. Schwartz-Shea (Eds.), Interpretation and method. Empirical research methods and the interpretive turn (pp. 316-330). Armonk, NY: M. E. Sharpe.

Puustinen, S., Mäntysalo, R., Hytönen, J., \& Jarenko, K. (2017). The "deliberative bureaucrat": Deliberative democracy and institutional trust in the jurisdiction of the Finnish planner. Planning Theory \& Practice, 18(1), 71-88.

Sandercock, L. (Ed.). (1998). Making the invisible visible: A multicultural planning history. Berkley, CA: University of California Press.

Sandercock, L. (2003). Out of the closet: The importance of stories and storytelling in planning practice. Planning Theory \& Practice, 4(1), 11-28.

Sandercock, L. (2010). From campfire to the computer: An epistemology of multiplicity and the story turn in planning. In L. Sandercock \& G. Attili (Eds.), Multimedia explorations in urban policy and planning (pp. 17-37). Dordrecht: Springer.

Savage, M., Longhurst, B., \& Bagnall, G. (2005). Globalization and belonging. London: SAGE.

Soja, E. W. (2003). Tales of a geographer-planner. In B. Eckstein \& J. A. Throgmorton (Eds.), Story and sustainability: Planning, practice, and possibility for American cities (pp. 207-224). Cambridge, MA: The MIT Press.

Statistics Finland. (2017a). Dwellings and housing conditions. Statistics Finland. Retrieved from https:// www.stat.fi/tup/suoluk/suoluk_asuminen_en.html

Statistics Finland. (2017b). Average prices of old dwellings in housing companies and numbers of transactions by postal code area and year of construction. Statistics Finland. Retrieved from http://pxnet2. stat.fi/PXWeb/pxweb/en/StatFin/StatFin_asu_ashi /statfin_ashi_pxt_004.px/?rxid=f3cc556d-a3dc-486aa94e-421b1f61b04b
Tampere. (2014). Tampereen väestö 31.12.2014 [The population of Tampere 31 December 2014]. Tampere: City of Tampere. Retrieved form http://www. tampere.fi/liitteet/v/uXEVsMcrE/Vaesto_31.12.2014. pdf

Tampere. (2015). Five-star city centre. Tampere City Centre Development Programme 2015-2030. Tampere: City Board of Tampere/City Centre Project. Retrieved from www.tampere.fi/tiedostot/f/7bu wGUnyn/tamperecitycentredevelopmentprogramme summary.pdf

Tampere. (2016). Keskustan strateginen osayleiskaava [The strategic city centre plan]. Tampere: City Board of Tampere/City Centre Project. Retrieved from www. tampere.fi/tiedostot/e/yqvkg7wJv/KSOYK_Kaavasel ostus_ehdotus_10.11.2015.pdf

Tampere. (2017). Tampereen keskustan korttelisuunnitelmat [Tampere city centre block plans]. Tampere: City Board of Tampere/City Centre Project. Retrieved from https://www.tampere.fi/tiedostot/t/ qifJxOYOh/Pinnin_pihat_26062017.pdf

Tampere. (2018). Tammelan täydennysrakentaminen [Tammela urban infill]. Tampere: City Board of Tampere/City Centre Project. Retrieved from https:// www.tampere.fi/tampereen-kaupunki/ohjelmat/kes kustahanke/tammelan-taydennysrakentaminen.html

Throgmorton, J. A. (1993). Survey research as rhetorical trope: Electric power planning arguments in Chicago. In F. Fischer \& J. Forester (Eds.), The argumentative turn in policy analysis and planning (pp. 117-144). London: Duke University Press.

Throgmorton, J. A. (1996). Planning as persuasive storytelling. The rhetorical construction of Chicago's electric future. Chicago, IL: University of Chicago Press.

Throgmorton, J. A. (2003). Planning as persuasive storytelling in a global-scale web of relationships. Planning Theory, 2(2), 125-151.

Van Hulst, M. (2012). Storytelling, a model of and a model for planning. Planning Theory, 11(3), 299-318.

Vision of Tammela. (2012). Tammelan yleissuunnitelma [Vision of Tammela]. Tampere: City Board of Tampere/City Centre Project. Retrieved from www. tampere.fi/liitteet/t/aBJgABTYy/Tammelan_yleissuun nitelma_Kh_2012_raportti.pdf

Wacklin, M. (1997). Tammela: Suutarien pääkaupunki [Tammela: Cobblers' capital]. Tampere: Tampereen Tammelalaiset ry.

Wacklin, M. (2008). Tammela: Tarinoita torin kulmilta [Tammela: Stories around the market place]. Tampere: Tampereen Tammelalaiset ry.

\section{About the Authors}

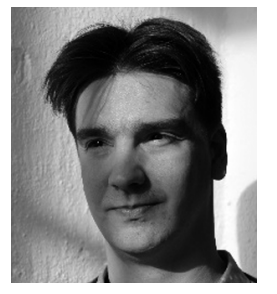

Antti Wallin, MSc, is a Doctoral Student in sociology, especially interested in the spatial aspects of social life. His dissertation dealing with the urban effects of population ageing will be completed in 2018. His previous publications have dealt with international retirement migration, urban sociability, cultural planning and social housing projects. He is currently studying strategic spatial planning at the University of Tampere, Finland. 


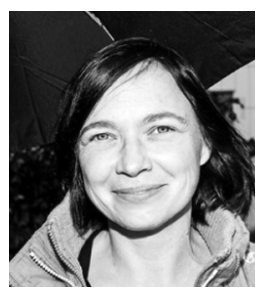

Helena Leino, PhD, is a Senior Lecturer in Environmental Policy in the School of Management at the University of Tampere. Her recent research has focused on practice-oriented policy analysis, sustainable city development, as well as participatory knowledge production in urban planning. She is currently the PI in two research projects (both funded by the Academy of Finland), Dwellers in Agile Cities (2016-2019) and Strategic Spatial Planning with Momentum Gaining Scenario Storytelling: Legitimacy Contested? (2015-2019).

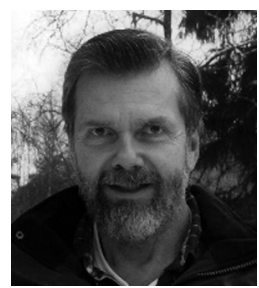

Ari Jokinen, PhD, works as a University Researcher in Environmental Policy at the Faculty of Management, University of Tampere, Finland. His research interest is in urban sustainability, particularly focusing on the intersection of humans, nature and technology. He is currently conducting research, which combines business organisations and urban nature-based solutions. His publications include studies on urban place in planning from the perspectives of affect, human-natural practices and neighbourhood identities.

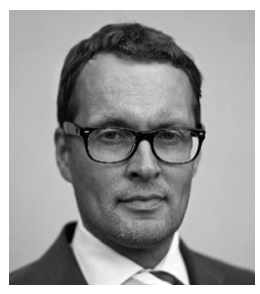

Markus Laine, PhD, is Senior Lecturer in Regional Studies in the School of Management, University of Tampere, Finland. His recent research has focused on land-use planning, housing, sustainable urban solutions and collaborative planning. He is currently the PI in Enabling City, a subproject of Dwellers in Agile Cities (funded by the Academy of Finland, 2016-2019).

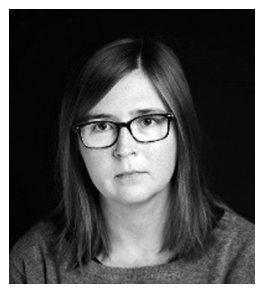

Johanna Tuomisaari, MSc (Admin), is currently a Doctoral Student at the Faculty of Management, University of Tampere. Her research interests include urban planning, strategic spatial planning, planning conflicts and urban nature. Her PhD thesis focuses on the relationship between strategic and statutory urban planning and how urban nature is dealt with in strategic planning.

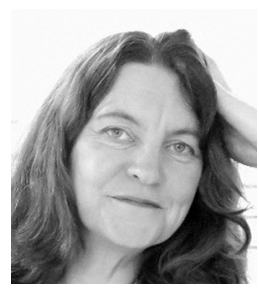

Pia Bäcklund, PhD, is a University Lecturer at the University of Helsinki (from April 2018). Her research interests concern the limits and the role of participation, democracy and planning theories and especially the knowledge base of planning practices and public administration in general. Presently, her research interest concerns city-regional planning cooperation, especially citizen participation in regional collaboration. 